\title{
PENGARUH MODEL PEMBELAJARAN GROUP INVESTIGATION MELALUI LESSON STUDY TERHADAP PENGUASAAN KONSEP IPA
}

\author{
Ni. N. Sudiasih ${ }^{1}$, G. Margunayasa ${ }^{2}$ \\ 1,2Jurusan Pendidikan Dasar, Universitas Pendidikan Ganesha \\ Singaraja, Indonesi \\ e-mail: ninengahsudiasih97@gmail.com ${ }^{1}$, pakgun pgsd@yahoo.com ${ }^{2}$
}

\begin{abstract}
ABSTRAK
Penelitian ini bertujuan untuk mengetahui perbedaan penguasaan konsep IPA antara siswa kelas IV semester genap yang mengikuti model pembelajaran group investigation melalui lesson study dengan siswa kelas IV semester genap yang mengikuti model pembelajaran konvensional di SD Gugus VII Kecamatan Kubutambahan. Jenis penelitian ini eksperimen semu dengan desain penelitin non-equivalent control post test control group desain. Populasi penelitian ini adalah seluruh siswa kelas IV SD Gugus VII Kecamatan Kubutambahan. Sampel penelitian diambil menggunakan teknik simple random sampling, sehingga diperoleh SDN 1 Bontihing sebagai kelas kontrol dan SDN 2 Bontihing sebagai kelas eksperimen. Data penguasaan konsep IPA dikumpulkan menggunakan tes objektif pilihan ganda, kemudian dianalisis menggunakan uji-t. Berdasarkan uji hipotesis diperoleh nilai thitung 2,65 , dengan demikian disimpulkan bahwa terdapat pengaruh yang signifikan perbedaan penguasaan konsep IPA antara siswa kelas IV semester genap yang mengikuti model pembelajaran group investigation melalui lesson study dengan siswa kelas IV semester genap yang mengikuti model pembelajaran konvensional di SD Gugus VII Kecamatan Kubutambahan.
\end{abstract}

Kata Kunci : Model Grup Investigation, Lesson Study, Penguasaan Konsep IPA

\begin{abstract}
This study aims to determine the differences in mastery of science concepts between the fourth grade students of the even semester who participated in the group investigation learning model through lesson study with the fourth grade students of the even semester who followed the conventional learning model in SD Gugus VII, Kubutambahan subdistrict. This type of research is a quasi-experimental design with a non-equivalent control post-test control group design. The population of this study was all fourth grade students of SD Gugus VII, Kubutambahan subdistrict. The research sample was taken using a simple random sampling technique, so as to obtain SDN 1 Bontihing as the control class and SDN 2 Bontihing as the experimental class. Data mastery of science concepts was collected using multiple choice objective tests, then analyzed using t-test. Based on hypothesis testing obtained 2.65 tcount greater than ttable 2.01 so that Ho is rejected, thus it is concluded that there is a significant influence of mastery of science concepts between fourth grade students of even semester who follow the group investigation learning model through lesson study with fourth grade students Even semester that follows conventional learning models in SD Gugus VII, Kubutambahan subdistrict.
\end{abstract}

Keywords : Model Group Investigation, Lesson Study, Mastery of The Science Concept 


\section{Pendahuluan}

Pembelajaran abad 21 mengharuskan siswa memiliki keterampilan dalam proses pembelajaran. Terdapat empat keterampilan yang disebut dengan indikator 4 C's (Rahmawati, dkk., 2017). Keterampilan tersebut terdiri dari critical thinking, creativity, communication dan collaboration (Nurazia dan Rahma Suwarma, 2018). Keterampilan 4 C's akan berguna untuk menjadi bekal hidup di masyarakat yang memiliki karakter baik lokal maupun global dan dapat dipertanggungjawabkan secara personal maupun sosial di masyarakat (Rahmawati, dkk., 2017). Melihat penting keterampilan harus dimiliki oleh siswa maka pondasi untuk membelajarkannya adalah pendidikan dasar. Di sisi lain empat keterampilan juga dapat dikembangkan dengan cara mempelajari berbagai disiplin ilmu (Rahmawati, dkk., 2017). Salah satu disiplin ilmu yang dimaksud adalah IPA (IImu Pengetahuan Alam).

IPA di SD dalam pelaksanaan pembelajarannya menekankan pada hakikat sains. Hakikat sains terdiri dari IPA sebagai sikap ilmiah yang perlu dikembangkan dalam proses pembelajaraan melalui kegiatan eksperimen, diskusi, dan simulasi. IPA sebagai produk yaitu pengetahuan yang diperoleh oleh siswa dari proses belajar yang dilakukannya. IPA sebagai proses adalah proses untuk mendapatkan produknya (Sudana, dkk., 2016). Mengacu pada hal itu, pembelajaran IPA menuntut seorang guru untuk dapat menciptakan pembelajaran yang berorientasi pada partisipasi, keaktifan, dan kerjasama kelompok. Siswa hendaknya mampu menemukan konsep-konsep melalui keterampilan berpikir kreatif dengan cara melakukan eksperimen (penyelidikan). Pembelajaran IPA di SD tidak cukup hanya melalui kumpulan fakta, prinsip-prinsip, hukum-hukum maupun teori tetapi juga harus menyangkut proses bagaimana kumpulan pengetahuan itu diperoleh. Dengan demikian kegiatan penyelidikan merupakan salah satu bagian integral dari pembelajaran IPA untuk melakukan pengamatan, memprediksi, mengidentifikasi yang anggotanya heterogen untuk meningkatkan penguasaan konsep siswa.

Berdasarkan survai yang dilakukan oleh Programme For International Student Assesmen (PISA), Organization For Economic Cooperation and Devolopment (OECD) mengemukakan bahwa Indonesia menempati peringkat ke-69 dari 76 negara dibidang sience (Wijaya, dkk., 2016), hal ini membuktikan bahwa proses pembelajaran sains belum optimal. Kegiatan lain seperti wawancara, pengamatan, dan pencatatan dokumen yang dilakukan selama 5 hari dimulai dari tanggal 10 sampai dengan 14 Desember di SD Gugus VII Kecamatan Kubutambahan 2018. Informasi yang diperoleh menunjukkan hal yang sama dengan survai yang dilakukan. Dari 6 sekolah secara keseluruhan terdapat 139 jumlah peserta didik, yang mencapai KKM sebanyak 50 orang dan yang tidak mencapai KKM sebanyak 89 orang. Data tersebut diperoleh informasi bahwa siswa yang mencapai KKM lebih sedikit dibandingkan dengan yang tidak mencapai KKM. Hal ini mencerminkan masih rendahnya kemampuan siswa dalam penguasaan konsep IPA, sehingga perlu diberikan perhatian khusus.

Berdasarkan pengamatan yang dilakukan, diketahui bahwa beberapa guru di lingkungan SD Gugus VII Kecamatan Kubutambahan dalam proses pembelajaran pada kegiatan awal tidak melaksanakan apersepsi. Apersepsi yaitu mengaitkan pengetahuan awal siswa dengan materi yang akan dibelajarkan. Pada kegiatan inti guru mengisi pembelajaran dengan kegiatan ceramah, siswa mencatat dari penjelasan guru dan pemberian tugas yang terpaku pada buku ajar. Pada kegiatan penutup tidak melaksanakan evaluasi. Proses pembelajaran itu tidak sesuai dengan kurikulum 2013 yang berlaku saat ini. Karena kegiatan lain seperti bereksperimen, partisipasi siswa dan kerjasama antar kelompok tidak terlihat, disisi lain pemberian tugas seperti mengerjakan soal-soal yang hanya terpaku dengan buku ajar yang masih bersifat hafalan. Soal pada buku ajar yang hanya terbatas pada hafalan mencakup tingkat mengingat $(\mathrm{C} 1)$. Tingkat mengingat termasuk dalam tingkatan kognitif yang masih tergolong rendah. Hal tersebut mengakibatkan rendahnya penguasaan konsep siswa. Dari kegiatan pencatatan dokumen dan pengamatan diketahui bahwa rendahnya penguasaan konsep IPA siswa sekolah dasar dikarenakan cara belajar yang berpusat pada guru. 
Berdasarkan wawancara dengan beberapa guru kelas IV yang mengajar di SD Gugus VII Kecamatan Kubutambahan diperoleh informasi bahwa (1) guru hanya membuat perangkat pembelajaran tanpa mengadakan kolaborasi antar guru lain bahkan jarang melaksanakan diskusi, (2) pada proses pembelajaran berlangsung belum pernah menerapkan open class artinya guru-guru lain tidak pernah menyaksikan secara langsung proses pembelajaran di kelas sehingga gerak gerik siswa tanpa adanya pengawasan, dan (3) guru tidak pernah mengadakan diskusi setelah berlangsungnya proses pembelajaran. Hal ini mengakibatkan proses pembelajaran jarang dikritisi oleh pendidik lainnya untuk dapat diberikan masukan-masukan terhadap penyusunan sampai dengan pelaksanaan terkait dengan perangkat pembelajaran dan akan menimbulkan dampak rendahnya penguasaan konsep IPA siswa kelas IV pada sekolah tersebut.

Salah satu alternatif untuk mengatasi permasalahan tersebut, ditawarkan solusi yakni dengan diterapkannya model pembelajaran group investigation melalui lesson study terhadap penguasaan konsep IPA. Model pembelajaran group investigation merupakan salah satu model pembelajaran kooperatif yang dapat diterapkan dalam pembelajaran IPA. Keunggulan dari penerapan model tersebut yakni (1) siswa lebih diberikan kesempatan untuk mandiri, (2) siswa lebih komunikatif menyampaikan permasalahan yang dihadapi, siswa untuk berpikir ilmiah, dan (3) siswa lebih berani untuk tampil (Aprilia, 2015).

Model group investigation adalah suatu model yang memberi kebebasan siswa untuk mengembangkan cara berpikir dan membuat siswa mengetahui kemampuan sendiri sehingga dengan mudah dapat mengenali sumber belajar di dalam maupun di luar kelas dalam setiap pembelajaran melalui penyelidikan (Mushoddik, dkk., 2016). Lesson study adalah model pembelajaran pelatihan profesional pendidik melalui penilaian pembelajaran berkelanjutan dan kolaboratif berdasarkan prinsip-prinsip kolegialitas untuk membangun komunitas pembelajaran (Fauziyah dan Uchitiawati, 2017). Berdasarkan hal tersebut lesson study dapat digunakan sebagai pengaturan untuk mengembangkan pembelajaran guna menciptakan pembelajaran yang mampu meningkatkan kemampuan mengajar guru secara berkelanjutan dengan tujuan dapat meningkatkan penguasaan konsep peserta didik.

Lesson study merupakan model pembinaan profesi guru, yang dalam pelaksanaannya terdiri dari tiga tahap yang harus dilakukan. Adapun tiga tahapannya, yaitu plan (merencanakan), do (melaksanakan), dan see (merefleksi) (Abizar, 2017). Setiap tahapan tersebut dilaksanakan oleh sekelompok guru secara kolaboratif, sehingga guru akan memperoleh banyak pendapat-pendapat yang berasal dari guru lain dengan pengalamanpengalaman berbeda. Melalui lesson study guru akan menemukan dan merancang pembelajaran yang mampu meningkatkan penguasaan konsep IPA peserta didik. Sehingga perlu dilakukan penelitian dengan judul "Pengaruh Model Pembelajaran Group Investigation melalui Lesson Study terhadap Penguasaan Konsep IPA siswa Kelas IV Semester Genap SD Gugus VII Kecamatan Kubutambahan Kabupaten Buleleng Tahun Pelajaran 2018/2019".

\section{Metode}

Penelitian ini adalah eksperimen semu maka bentuk desain eksperimen semu (quasy experimental design) yang digunakan dalam penelitian ini yaitu non-equivalent post-test control group design. Rancangan tersebut dipilih karena tujuan dari penelitian ini adalah mengetahui perbedaan penguasaan konsep siswa yang terjadi setelah dibelajarkan model pembelajaran group investigation melalui lesson study pada siswa kelas IV SD Gugus VII Kecamatan Kubutambahan. Pada rancangan non-equivalent post-test only control group design terdapat dua kelompok yang dipilih secara random dengan masing-masing sebagai kelas eksperimen dan kelas kontrol. Adapun rancangan penelitian yang digunakan sebagai berikut. 
Tabel 1. Rancangan Penelitian

\begin{tabular}{|c|c|c|}
\hline Kelas & Perlakuan & Post-test \\
\hline $\begin{array}{l}\text { Eksperimen } \\
\text { Kontrol }\end{array}$ & $\begin{array}{c}X_{1} \\
- \\
\end{array}$ & $\begin{array}{l}\mathrm{O}_{1} \\
\mathrm{O}_{2}\end{array}$ \\
\hline
\end{tabular}

Populasi adalah keseluruhan objek dalam suatu penelitian (Agung, 2014). Populasi pada penelitian adalah seluruh siswa semester genap kelas IV yang terdapat pada Gugus VII Kecamatan Kubutambahan Kabupaten Buleleng 2018/2019 sebesar 139 orang dari 6 sekolah yang terdapat. Selanjutnya populasi tersebut di uji kesetaraanya menggunakan ANAVA A, apabila sebaran data setara maka dapat ditentukan sampel penelitian ini. Berdasarkan perhitungan Anava dilakukan pada taraf signifikan 5\%. Melalui hasil uji anava diperoleh hasil nilai $F_{\text {hitung }}$ adalah 2, 077 sedangkan $F_{\text {tabel }}$ pada taraf $5 \%$ adalah 2, 29 yang dapat dilihat dari df pembilang $(\mathrm{a}-1=6-1=5)$ dan df penyebut adalah $(\mathrm{N}-\mathrm{a}=139-6=133)$, sehingga dari hasi perhitungan tersebut menunjukkan bahwa $F_{\text {hitung }}<F_{\text {tabel }}$ maka dapat dinyatakan tidak terdapat perbedaan yang signifikan penguasaan konsep siswa kelas IV pada mata pelajaran IPA di SD Gugus VII Kecamatan Kubutambahan. Hasil analisis uji kesetaraan pada penelitian ini dapat diinterprestasikan, yaitu hasil tes awal siswa kelas IV pada mata pelajaran IPA siswa di SD di Gugus VII Kecamatan Kubutambahan adalah setara.

Populasi yang sudah setara dapat dilanjutkan untuk menentukan sampel penelitian menggunakan teknik random sampling dengan cara diundi 2 kali. Populasi yang diundi sebanyak 6 sekolah sehingga diperoleh SDN 1 Bontihing dengan jumlah siswa 23 orang menjadi kelas kontrol dan 28 siswa di SDN 2 Bontihing menjadi kelas eksperimen. Variabel yang digunakan pada penelitian ini yaitu bebas dan terikat, variabel bebas yaitu group investigation melalui lesson study adalah guru melakukan kolaborasi dengan guru lainnya untuk merancang dan melaksanakan pembelajaran menggunakan model pembelajaran group investigation.

Namun pada penelitian eksperimen ini harus dapat memperlihatkan adanya perubahan variabel terikat yang mengakibatkan dari adanya perlakuan variabel bebas yang ditentukan oleh faktor-faktor lain seperti validitas internal. Validitas internal adalah pengontrolan peneliti terhadap variabel-variabel yang dapat mempengaruhi hasil dari kelompok eksperimen (Setyosari, 2012). Adapun beberapa ancaman yang dapat mempengaruhi validitas internal yaitu hilangnya subjek (mortality), kematangan, implementasi, dan instrumentasi (Setyosari, 2012). Pengontrolan subjek, berkaitan pada intlektual dan umur setiap individu yang dipilih sebagai sampel, dari hal tersebut menimbulkan dampak antara kelas kontrol dan eksperimen layak untuk di bandingkan. Pengontrolan hilang subjek (morality) pada saat proses pembelajaran berlangsung. Pada pengontrolan implentasi adalah ketidak sesuai instrumen yang diterapkan tidak sesuai dengan yang sudah dirancang. Instrumen yang dimaksud adalah RPP dan media. Untuk dapat mengatasi semua faktor yang sudah dijabarkan yaitu melakukan uji kesetaraan dan memilih sampel yang setara, setiap pelaksanaan perlu dilakakukanya absensi dan pengaturan waktu di kelas kontrol dan eksperimen, serta melakukan penyeragaman indikator pada kelas eksperimen dan kontrol.

Pada penelitian ini validitas eksternal perlu pula diperhatikan, validitas eksternal adalah harapan bahwa hasil-hasil penelitian dapat diaplikasikan pada situasi atau kelompok yang lebih banyak dan waktu serta lokasi lebih luas. Dengan demikian, adapun faktor yang mempengaruhinya pada penelitian ini yaitu efek seleksi terhadap sampel dan efek prosedur eksperimen yaitu (a) Efek seleksi terhadap sampel berarti pengambilan sampel dalam jenis penelitian haruslah mewakili populasi sehingga tidak terjadi generalisasi yang dihasilkan berlaku bagi sampel dan populasi lebih luas dan (b) Efek prosedur eksperimen, yaitu sampel yang menyadari bahwa dirinya sedang dieksperimen menyebabkan generalisasi yang diperoleh bisa tdak berlaku bagi populasi. Hal ini terjadi karena adanya perbedaan pengalaman antar anggota sampel dengan populasi sehingga perlu dilakukan kontrol terhadap pengaruh prosedur eksperimen. 
Sedangkan variabel terikat yaitu penguasaan konsep IPA adalah skor hasil belajar ranah kognitif. Pengumpulan data digunakan dengan metode tes pilihan ganda. Adapun materi yang digunakan pada penelitian ini adalah TEMA 8 yaitu Daerah Tempat Tinggalku. Sebelum instrumen itu digunakan pengambilan data perlu dilakukan pengujian instrumen dengan 4 uji yaitu uji pakar, uji validitas, uji reliabilatas, uji taraf kesukaran dan uji daya beda. Instrumen tersebut harus sudah memenuhi kriteria agar dapat digunakan. Instrumen penelitian ini sejumlah 36 butir soal dengan diadakannya berbagai uji sehingga hanya 30 butir soal yang dapat digunakan dalam penelitian ini. Pengujian hipotesis menggunakan stastistik deskritif dan infrensial (uji-t). Statistik deskriptif berfungsi untuk menjadikan data bermakna, yang diantaranya dapat disajikan dengan ukuran tendensi sentral (mean, median, dan modus dan standar deviasi) (Agung, 2016). Selain itu, analisis deskriptif digunakan untuk mengetahui tinggi rendahnya kualitas dari variabel, yaitu penguasaan konsep siswa.

Analisis infresial untuk penguji hipotesis dengan menggunakan uji-t. Uji prasyarat untuk normalitas digunakan teknik chi squre dengan ketentuan chi hitung < chi tabel dengan taraf signifikansi 5\% dan homogenitas data dikatakan homogen apabila $F_{\text {hitung }}<F_{\text {tabel }}$ dengan taraf signifikansi 5\% menggunakan uji F. Setelah data berdistribusi normalitas dan homogenitas, dilanjutkan uji hipotesis menggunakan uji-t. Uji-t. hipotesis yang diuji adalah terdapat perbedaan yang signifikan penguasaan konsep IPA siswa yang dibelajarkan dengan model pembelajaran group investigation melalui seting lesson study dan siswa yang tidak dibelajarkan dengan model pembelajaran group investigation melalui lesson study siswa kelas IV semester Genap SD Gugus VII Kecamatan Kubutambahan Kabupaten Buleleng Tahun Pelajaran 2018/2019. Lebih lanjut, dilakukannya uji hipotesis menggunakan uji-t. Uji-t yang digunakan memiliki kriteria yaitu nilai $t_{\text {hitung }}<t_{\text {tabel }}$, maka Ho diterima dan $\mathrm{H} 1$ ditolak, dan jika $t_{\text {hitung }} \geq t_{\text {tabel, }}$ maka Ho ditolak dan $\mathrm{H} 1$ diterima. Pengujian dilakukan pada taraf signifikansi 5\% dengan derajat kebebasan $\mathrm{dk}=\mathrm{n} 1+\mathrm{n} 2-2$.

\section{Hasil dan Pembahasan}

Data hasil penelitian ini meliputi data penguasaan konsep IPA siswa yang dibelajarakan dengan model pembelajaran group invesigation melalui lesson study dan siswa yang dibelajarkan tidak menggunakan model pembelajaran group investigation melalui lesson study. Adapun rekapan deskripsi data hasil penguasaan konsep IPA siswa dapat dilihat pada Tabel 2.

Tabel 2. Rekapan Deskripsi Data Hasil Penguasaan Konsep IPA

\begin{tabular}{lcc}
\hline \multirow{2}{*}{ Statistik Deskriptif } & \multicolumn{2}{c}{ Hasil Penguasaan Konsep IPA } \\
\cline { 2 - 3 } & Kelompok Eksperimen & Kelompok Kontrol \\
\hline Mean & 19,55 & 14,55 \\
Median & 19,75 & 14,05 \\
Modus & 20,50 & 13,95 \\
Varians & 48,30 & 40,96 \\
Standar Deviasi & 6,95 & 6,40 \\
Skor Maksimum & 30 & 30 \\
Skor Minimum & 4 & 3 \\
Rentangan & 27 & 28 \\
Panjang Kelas & 5 & 5 \\
Banyak kelas & 6 & 6 \\
\hline
\end{tabular}

Bersumber dari Tabel 2 data penguasaan konsep IPA siswa yang dibelajarkan menggunakan model pembelajaran group investigation melalui lesson study sebagai kelompok eksperimen terhadap 28 siswa menunjukkan skor tertinggi adalah 30 dan skor terendah adalah 4. Berdasarkan hasil perhitungan diproleh rentangan 27; banyak kelas 6; panjang kelas 5; modus $(\mathrm{Mo})=20,50$; median $(\mathrm{Md})=19,75$; mean $(\mathrm{Me})=19,55$; standar 
deviasi $(S D)=6,95$ dan varians $\left(s^{2}\right)=.48,30$. Lebih lanjut data penguasaan konsep IPA disajikan dalam bentuk grafik poligon.

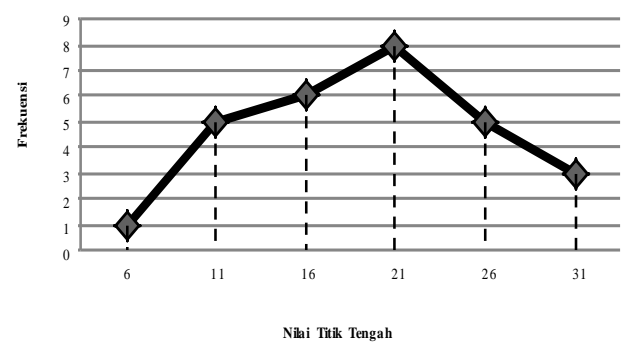

Gambar 1. Grafik poligon data penguasaan konsep IPA kelompok eksperimen

Selanjutnya dikonversi ke dalam skala teoritik penilaian untuk dapat mengetahui kualitas variabel penguasaan konsep IPA pada kelas eksperimen. Kualitas data penguasaan konsep IPA diketahui bahwa rata-rata termasuk kategori tinggi, yaitu 19,55 karena berada pada rentangan skor $17,50 \leq \mathrm{M} \leq 22,50$. Bersumber pada Tabel 2 data penguasaan konsep IPA siswa yang tidak dibelajarkan menggunakan model pembelajaran group investigation melalui lesson study sebagai kelompok kontrol terhadap 23 siswa menunjukkan skor tertinggi adalah 30 dan skor terendah adalah 4. Dari hasil perhitungan diproleh rentangan 28; banyak kelas 6; panjang kelas 5 ; modus $(\mathrm{Mo})=13,95$; median $(\mathrm{Md})=14,05$; mean $(\mathrm{Me})=14,55$; standar deviasi $(\mathrm{SD})=6,40$ dan varians $\left(\mathrm{s}^{2}\right)=.40,96$. Lebih lanjut data penguasaan konsep IPA disajikan dalam bentuk grafik poligon.

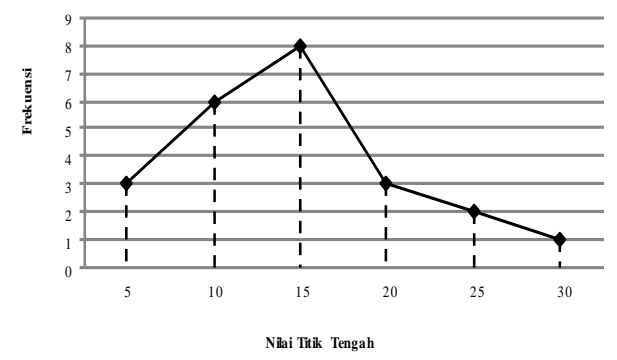

Gambar 2. Grafik poligon data penguasaan konsep IPA kelompok kontrol

Selanjutnya dikonversi ke dalam skala teoritik penilaian untuk dapat mengetahui kualitas variabel penguasaan konsep IPA pada kelas kontrol. Kualitas data penguasaan konsep IPA diketahui bahwa rata-rata termasuk kategori tinggi, yaitu 14,55 karena berada pada rentangan skor $12,50 \leq \mathrm{M} \leq 17,50$. Sebelum dilakukan uji hipotesis, perlu dilakukan uji normalitas dan homogenitas terhadap data data skor penguasaan konsep IPA melalui posttest. Data penguasaan konsep IPA berdistribusi normal antara siswa yang dibelajarkan dengan menggunakan model pembelajaran group investigation melalui lesson study dan siswa yang tidak dibelajarkan menggunakan model pembelajaran group investigation melalui lesson study. Hal ini dapat ditunjukkan dari nilai chi hitung kelas eksperimen 1,44 dan kelas kontrol 2,05 lebih kecil dari nilai chi tabel 11,07. Sedangkan uji homogenitas berdasarkan hasil perhitungan diperoleh nilai $F_{\text {hitung }}=1,18$ dan $F_{\text {tabel }}=4,04$. Hal ini berarti $F_{\text {hitung }} \leq F_{\text {tabel, }}$, sehingga data kedua kelompok memiliki varians yang homogen.

Mengacu pada uji prasyarat karena data penguasaan konsep IPA sudah normalitas dan homogen, maka dilanjutkan pada uji hipotesis. Berdasarkan hasil perhitungan uji-t, diperoleh $t_{\text {hitung }}=2,65$ dan $t_{\text {tabel }}=2,10$ pada taraf signifikansi $5 \%$. Dengan demikian, nilai $t_{\text {hitung }}>t_{\text {tabel }}$ yakni 2,65>2,01 sehingga $H_{0}$ ditolak. Hal ini menunjukkan bahwa terdapat perbedaan penguasaan konsep IPA antara siswa yang dibelajarkan dengan model pembelajaran group investigation melalui lesson study dan siswa yang tidak dibelajarkan 
menggunakan model pembelajaran group investigation melalui lesson study pada siswa kelas IV semester genap di SD Gugus VII Kecamatan Kubutambahan Kabupaten Buleleng Tahun Pelajaran 2018/2019.

Berdasarkan deskripsi data hasil penelitian yang sudah dilakukan, diketahui bahwa terdapat perbedaan penguasaan konsep IPA antara siswa yang dibelajarkan model pembelajaran group investigation melalui lesson study dan siswa yang tidak dibelajarkan model pembelajaran group investigation melalui lesson study. Siswa yang mengikuti pembelajaran dengan model pembelajaran group investigation melalui lesson study memilik hasil penguasaan konsep IPA lebih tinggi dibandingkan dengan siswa yang mengikuti pembelajaran tidak menggunakan model pembelajaran group investigation melalui lesson study. Hal ini dilihat dari hasil uji-t yang telah diperoleh, yaitu nilai $t_{\text {hitung }} 2,65$ sedangkan nilai $t_{\text {tabel }}$ pada taraf signifikasi 5\%, yaitu 2,01.

Dengan demikian adanya perbedaan penguasaan konsep dari kedua kelompok, menandakan bahwa model pembelajaran group investigation melalui lesson study berpengaruh terhadap penguasaan konsep IPA siswa. Hal ini disebabkan oleh langkahlangkah dari model pembelajaran group investigation yang mampu melibatkan seluruh siswa untuk berpartisipasi aktif dalam kegiatan kelompok seperti mengamati, mencoba, memprediksi dan membangun pengetahuannnya secara mandiri, sehingga dapat membentuk penguasaan konsep. Salah satunya pada mata pelajaran IPA.

Tahap pertama, model pembelajaran group investigation adalah grouping. Grouping yaitu mengidentifikasi topik dan mengatur siswa kedalam kelompok yang bersifat heterogenitas (Mushoddik, dkk., 2016). Dengan adanya kegiatan mengidentifikasi topik tersebut dapat mendorong siswa untuk berpartisipasi aktif dalam proses pembelajaraan. Setelah masing-masing kelompok diberikan LKPD, siswa mengidentifikasi topik dengan menuliskan jawaban terhadap masalah yang diberikan. Siswa menjawab permasalahan berdasarkan pengetahuan awal yang dimilikinya. Berdasarkan kemampuan siswa memprediksi jawaban dari masalah yang diberikan dengan pengetahuan awal, maka secara tidak langsung siswa sudah mengembangkan dimensi ranah kognitif C3 yang menuntut siswa untuk mampu menerapkan konsep yang di kuasainya.

Tahap kedua, model pembelajaran group investigation adalah planning. Pada tahap planning, siswa secara aktif dituntut untuk merencanakan kegiatan dan membuat strategi serta membagi tugas untuk dapat memecahkan permasalahan. Kegiatan ini terlihat dari proses pembelajaran yang sudah dilaksanakan oleh peneliti, sesudah guru menyampaikan topik-topik yang akan di bahas dan media yang sudah di bagikan. Siswa akan melaksanakan diskusi mengenai tugas yang diberikan agar dapat menentukkan langkah-langkah yang akan di ambil. Mengacu pada kegiatan itu dapat melatih kemandirian siswa. Hal ini sejalan dengan kelebihan dari model group investigation yaitu siswa diberikan kesempatan untuk lebih mandiri (Aprilia, 2015). Kegiatan seperti membagi dan merencanakan tugas memerlukan suatu tindakan berupa pemberian keputusan. Pemberian keputusan salah bentuk untuk mengembangkan ranah kognitif pada tingkat $\mathrm{C} 5$ yaitu mengevaluasi.

Tahap ketiga adalah investigation, sesuai dengan pembagian tugas yang sudah di rancang pada tahap planning maka pada tahap ini siswa mengumpulkan informasi sesuai dengan topik yang dipelajari. Pada tahap ini, informasi diperoleh dengan mengamati dan mencoba dari media yang diberikan oleh guru. Setelah melakukan kegitan mencoba, siswa mencatat hasil temuan-temuan yang diperoleh. Dengan melakukan kegiatan tersebut siswa dapat melatih kemampuan berpikir ilmiah pada kegiatan mencoba (Anita, dkk., 2013). Kegiatan ini mampu meningkatkan penguasaan konsep siswa. Dengan demikian secara tidak langsung sudah mengembangkan ranah kognitif yaitu $\mathrm{C} 1$ pada kegiatan mencatat dan C3 pada kegiatan menggunakan prosedur percobaan. Kegiatan investigasi tidak diberikan pada kelas kontrol.

Tahap keempat adalah organizing, siswa mempersiapkan laporan setelah kegiatan investigation. Pada tahap ini antar anggota kelompok melaksanakan diskusi terkait temuan yang didapatkan untuk membuat laporan. Hal ini nampak pada kegiatan pembelajaran setelah siswa melakukan percobaan. Terjadinya tukar pikiran antar anggota kelompok dapat mengembangkan kemampuan berpikir kritis siswa. Hal ini sejalan dengan pendapat 
Istikomah, dkk (2010) yang menyatakan dalam pembelajaran group investigation siswa berperan sebagai seorang ilmuwan maka siswa mampu terbuka dalam menerima pendapat dari orang lain, dan teliti demi memperoleh informasi sevalid mungkin sehingga siswa mampu berpikir kritis. Melalui diskusi, siswa mampu mengkonstruksi penguasaan konsep IPA. Dengan demikian diskusi membantu siswa untuk mendapatkan berbagai perspektif baru terhadap sebuah permasalahan. Pada tahap organizing, siswa dapat mengembangkan kemampuan berpikir kritis. Dengan kemampuan berpikir kritis, siswa dapat melatih diri untuk mengemukakan pendapat, menanggapi pendapat, menunjukkan kelebihan maupun kekurangan, mengaitkan pendapat, dan menyimpulkan berbagai pendapat. Mengacu dengan hal tersebut siswa dapat mengembangkan ranah dimensi kognitif yaitu C2 sampai dengan C5.

Tahap kelima adalah presenting, pada tahap ini siswa dari masing-masing perwakilan kelompok maju ke depan kelas untuk mempresentasikan laporan yang dibuat pada tahap organizing. Kegiatan ini bertujuan untuk meningkatkan rasa percaya diri siswa dan berpikir dalam berargumentasi, sehingga siswa mempunyai keterampilan berkomunikasi dengan baik pada orang lain tanpa ragu. Selain itu kegiatan persentasi memberikan kesempatan siswa untuk berbagi pengetahuan yang telah dimilikinya. Perilaku ini nampak saat proses pembelajaran berlangsung ketika siswa melaksanakan presentasi di depan kelas. Hal ini sejalan dengaan pendapat Mushoddik, dkk., (2016) yang mengungkapkan bahwa presentasi di kelas dapat melatih rasa percaya diri dan kemampuan berpikir dalam berargumentasi. Kegiatan presentasi dapat melatih kemapuan berkomunikasi siswa dan penguasaan konsep. $\mathrm{Hal}$ ini dikarenakan siswa harus mampu menguasai konsep sebelum melakukan presentasi. Kegiatan tersebut dapat mengembangan ranah dimensi kognitif C2.

Tahap evaluating, pada tahap ini setiap kelompok mendapatkan masukan dari kelompok lain dan guru. Masing-masing kelompok dapat mengembangkan sikap lebih komunikatif sehingga lebih percaya diri dalam mengemukakan pendapat. Hal tersebut sesuai dengan salah kelebihan dari model group investigation itu sendiri dan dapat meningkatkan penguasaan konsep siswa lebih baik lagi.

Berdasarkan temuan-temuan pada kelompok eksperimen, dapat diketahui bahwa model pembelajaran group investigation memiliki keunggulan yang mampu memberikan pengaruh positif bagi pembelajaran dengan terwududnya pembelajaran yang kondusif dan lebih aktif sehingga tepat untuk diterapkan dalam pembelajaran. Hal ini nampak dari beberapa keunggulan yang dimiliki model pembelajaran group investigation adalah 1) proses pembelajaran lebih berpusat pada siswa, sehingga kesempatan untuk lebih mandiri untuk mencari, membentuk, dan mengembangkan konsep sesuai kemampuannya, 2) adanya sintaks dari model pembelajaran group investgation membantu siswa untuk menguasai konsep-konsep tertentu dalam kegiatan investigasi, sehingga siswa dapat berpikir ilmiah 3) melatih siswa berargumen agar dapat memiliki keterampilan komunikasi yang baik dan 4) mengembangkan interaksi, kerjasama, dan keterlibatan siswa dalam pembelajaran. Beberapa hal ini menjadikan model group investigation lebih unggul dibandingkan dengan pembelajaran konvensional. Pembelajaran konvensional merupakan pembelajaran yang bersifat teacher center, sehingga pembelajaran lebih didominasi oleh guru sedangkan siswa hanya menerima secara pasif. Tidak terdapatnya interaksi yang bersifat multi arah pada pembelajaran konvensional, sehingga mengakibatkan proses pembelajaran tidak terlaksana dengan maksimal dalam pembentukan konsep siswa. Berdasarkan hal tersebut, tahap-tahap pembelajaran yang tidak dibelajarkan menggunakan group investigaton adalah 1) guru menyampaikan tujuan pembelajaran, 2) guru memberikan informasi tentang materi, siswa mendengarkan penjelasan guru, 3) siswa mencatat apa yang disampaikan oleh guru (4 tanya jawab, 4) penugasan, dan 5) guru menyimpulkan kegiatan pembelajaran. Mengacu pada tahap-tahapan tersebut, dapat diketahui bahwa pembelajaran yang tidak menggunakan model pembelajaran group investigation tidak memberikan kesempatan yang luas kepada siswa untuk menggali dan mengkonstruksi informasi sesuai kemampuannya, sehingga sulitnya siswa untuk menguasai konsep yang diberikan oleh guru.

Selain penerapaan model pembelajaran group investigation, hal yang ikut berperan penting yaitu dengan diterapkannya lesson study untuk dapat meningkatkan kemampuan 
guru dalam merancang, melaksanakan dan mengevaluasi pembelajaran. Dengan penerapan lesson study, guru harus berkolaborasi dengan tim lesson study untuk melaksankan kegiatan tersebut. Penerapan lesson study dapat mempengaruhi perbedaan penguasaan konsep siswa pada kelas kontrol dan kelas eksperimen. Lesson study memberikan kesempatan pada guru untuk melakukan perbaikan cara mengajar sesuai prinsip-prinsip kogelitas dengan proses belajar mengajar untuk mendapat masukan dan pendapat kelompok guru yang terlibat (Nashruddin dan Nurrachaman, 2016). Dalam penelitian ini, lesson study menjadi acuan atau dasar berpikir di dalam kegiatan perencanaan pembelajaran, pelaksanaan pembelajaran, dan evaluasi pembelajaran, sesuai dengan tahapan lesson study yaitu, plan, do, dan see (Abizar, 2017).

Mengacu pada tahap-tahapan tersebut yaitu tahapan perencanaan (plan) guru beserta tim lesson study merancang RPP, menyiapkan media pembelajaran, menyususun soal evaluasi, dan mempelajari model yang diterapkan agar proses pembelajaran bermakna. Pada penelitian ini, model pembelajaran telah ditentukan yaitu model pembelajaran group investigation, sehingga diskusi lebih difokuskan pada hal-hal yang perlu diperhatikan dari model pembelajaran group investigation agar sesuai dengan kebutuhan siswa. Diskusi ini bertujuan untuk membentuk model pembelajaran group investigation yang mampu menjadikan penguasaan konsep IPA siswa menjadi lebih baik. Pada tahapan melaksanakan (do) dilaksankaannya open class yaitu guru model mengajar dengan menerapkan apa yang sudah di rancang yaitu model pembelajaran group investigation, tim yang lain sebagai observer bertugas mengamati perilaku atau gerak-gerik siswa dalam mengikuti proses pembelajaran. Sedangkan pada tahap see, para observer melakukan diskusi bersama guru model dan tim tentang reaksi siswa terhadap model pembelajaran group investigation yang dibelajarkan sebelumnya. Berdasarkan hal itu, hasil temuan yang didapat dengan diterapkannya lesson study mampu memperbaiki atau menyempurnakan setiap langkah pembelajaran model group investigation yang mampu mengembangkan penguasaan konsep siswa.

Hasil temuan pada penelitian ini sesuai dengan hasil penelitian yang dilakukan oleh Ariawan, dkk (2016) yang mengungkapkan bahwa dengan diterapkannya model pembelajaran group investigation dapat menjadikan hasil belajar siswa khususnya pada mata pelajaran IPA lebih baik daripada dibelajarkan dengan model pembelajaran konvensional, hal ini membuktikan bahwa model pembelajaran group investigation dapat membawa pengaruh yang positif bagi siswa. Penelitian lain yang memperoleh hasil serupa adalah penelitian yang dilakukan oleh Budiastra (2016) yang menyatakan pembelajaran IPA menggunakan model pembelajaran group investigation menghasilkan peningkatan keterampilan kemampuan berpikir kritis nsiswa pada mata pelajaran IPA siswa. Hal ini menunjukkan bahwa, model pembelajaran group investigation melalui lesson study berpengaruh terhadap penguasaan konsep IPA siswa kelas IV di SD Gugus VII Kecamatan Kubutambahan Kabupaten Buleleng Tahun Pelajaran 2018/2019.

\section{Simpulan dan Saran}

Berdasarkan hasil pengujian hipotesis dan pembahasan sehingga simpulan pada penelitian ini terdapat perbedaan yang signifikan penguasaan konsep IPA antara siswa yang dibelajarkan dengan model pembelajaran group investigation melalui lesson study dan siswa yang tidak dibelajarkan dengan menggunakan model pembelajaran group investigation melalui lesson study pada siswa semester genap kelas IV SD di Gugus VII Kecamatan Kubutambahan Kabupaten Buleleng Tahun Pelajaran 2018/2019.

Berdasarkan hasil penelitian diperoleh terdapat beberapa sarana yang diajukan sebagai berikut. (1) Kepada guru yang mengajar muatan mata pelajaran IPA SD disarankan menggunakan model group investigation pada pembelajaran IPA. Model pembelajaran group investigation melalui lesson study dapat melatih siswa untuk menumbuhkan berpikir kritis. Keterlibatan siswa secara aktif nampak dari tahap pertama sampai dengan tahap akhir pembelajaran, sehingga dapat berpengaruh positif pada peningkatan penguasaan konsep IPA. Sebaiknya pada saat diterapkannya model ini, guru memperhatikan beberapa tahapan. 
Pada tahap investigation, guru tidak hanya melaksankanakan kegiatan investigasi di dalam kelas, namun juga dapat dilaksanakan ditempat-tempat lain yang relevan dengan materi yang dibelajarkan. Hal ini bertujuan untuk mencegah rasa bosan pada diri siswa. Selain itu guru harus merancang suatu kegiatan yang dapat membuat siswa melakukan investigasi seperti melakukan percobaan. (2) Siswa pada saat mengikuti proses pembelajaran diharapkan keterlibatan untuk berpartisipasi aktif melakukan interaksi dengan teman di kelompoknya. Siswa yang sudah memahami topik pembelajaran dapat menjelaskan dengan anggota kelompok, teman yang belum memhami topik pembelajaran bisa bertanya kesalah satu anggota kelompok yang sudah memahami sehingga pembentukan kelompok secara heterogen terlaksanakan. Siswa juga diharapkan bersikap terbuka yang artinya belajar saling menerima pendapat teman, serta tidak memaksakan pendapat pribadi pada saat tahap organizing dan presenting. (3) Sekolah hendaknya memperkenalkan dan mengembangkan lebih lanjut model pembelajaran group investigation melalui lesson study kepada para guru sebagai salah satu alternatif pembelajaran. Proses pengenalan dan pengembangan model pembelajaran group investigation dapat dilakukan melalui pertemuan-pertemuan formal seperti pertemuan KKG atau pelatihan-pelatihan pembelajaran. Selain itu sekolah sebaiknya menyediakan alat dan bahan sebagai penunjang guna pembelajaran menjadi lebih inovatif. Dan (4) Kepada para peneliti yang berminat mengadakan penelitian lebih lanjut mengenai penerapan model group investigation melalui lesson study bidang IPA dan bidang ilmu lainnya hendaknya memperhatikan kendala-kendala yang dialami pada penelitian ini seperti jumlah siswa yang melebihi dari rombongan belajar pada kelas sehingga kesulitan pada pembentukan kelompok sebagai bahan pertimbangan untuk perbaikan dan penyempurnaan penelitian yang dilaksanakan.

\section{Daftar Pustaka}

Abizar, Hariz. 2017. Buku Master Lesson Study. Yogyakarta: DIVA Press.

Agung, Anak Agung Gede. 2014. Metodologi Penelitian Pendidikan. Singaraja: Aditya Media Publishing.

Agung, Anak Agung Gede. 2016. Statistika Inferensial. Singaraja: Fakultas IImu Pendidikan.

Anderson, L. W. \& Krathwohl, D. R. 2010. Kerangka Landasan untuk Pembelajaran, Pengajaran, dan Asesmen. Terjemahan A. Prihantoro. A Taxonomy for Learning, Teaching, and Assesing: a Revision of Bloom's Taxonomy of Educational Objectives. 2001". Yogyakarta: Pustaka Pelajar.

Ariawan, dkk. 2016. "Pengaruh Model Pembelajaran Kooperatif Tipe Group Investigation Media Lingkungan Terhadap Hasil Belajar IPA Siswa Kelas IV Di Desa Sidetapa". Jurnal PGSD Universitas Pendidikan Ganesha. Vol. 4, No. 1 (hlm. 1-10).

Ayuwanti, Irma. 2016. "Meningkatkan Aktivitas Dan Hasil Belajar Matematika Menggunakan Model Pembelajaran Kooperatif Tipe Group Investigation Di SMK Tuma'ninah Yasin Metro". Jurnal SAP. Vol. 1, No. 2 (hlm. 105-114).

Budiastra, dkk. 2015. "Pengaruh Model Kooperatif Tipe GI (Group Investigation) Terhadap Keterampilan Berpikir Kritis Dalam Pembelajaran IPA". Journal PGSD Universitas Pendidikan Ganesha. Vol. 3, No. 1.

Budiastra, dkk. 2015. "Pengaruh Model Kooperatif Tipe GI (Group Investigation) Terhadap Keterampilan Berpikir Kritis Dalam Pembelajaran IPA". Journal PGSD Universitas Pendidikan Ganesha. Vol. 3, No. 1. 
Istikomah, dkk. 2010. "Penggunaan Model Pembelajaran Group Investigation Untuk Menumbuhkan Sikap Ilmiah Siswa". Jurnal Pendidikan Fisika Indonesia. Vol. 6. (HIm. 40-43)

Mushoddik, dkk. 2016. "Pengaruh Model Pembelajaran Group Investigation Terhadap Kemampuan Berpikir Kritis Siswa MAN 6 Jakarta (Group Investigation Learning Model Influence on Critical Thinking Skills of MAN 6 Students Jakarta)". Jurnal Geografi Education. Vol. 5, No. 2 (hlm. 1-10).

Nashruddin dan Nurrachamn, 2016. "The Implementation of Lesson Study in English Language Learning: A Case Study". Jurnal Dinamika IImu. Vol. 16, No. 2 (hlm. 169176).

Nuraziza dan Rahma Suwarma, 2018. "Menggali Keterampilan Creative Problem Solving Yang Dimiliki Siswa SMP Melalui Pembelajaran IPA Berbasis STEM". Jurnal Wahana Pendidikan Fisika. Vol. 3, NO. 1 (hlm. 56-61).

Rahmawati, dkk. 2017. "Pengembangan Indikator 4 C's Yang Selaras Dengan Kurikulum 2013 Pada Mata Pelajaran MatematikaSMP/MTS Kelas VIII Semester 1". Jurnal Kadikma. Vol. 8, No. 3 (hlm. 21-30).

Richvana, dkk. 2012. "Pengaruh Model Pembelajaran Group Investigation Terhadap Hasil Belajar Biologi Ditinjau Dari Tingkat Kreativitas Siswa Kelas X SMAN 2 Karanganyar". Jurnal Pendidikan Biologi. Vol. 4, No. 1 (hlm. 1-14).

Setyosari, P. 2012. Metode Penelitian Pendidikan dan Pengembagan. Jakarta: Prenada Media Group

Sulthon. 2016. "Pembelajaran IPA Yang Efektif Dan Menyenangkan Bagi Siswa Madrasah Ibtidaiyah (MI)". Jurnal Elementary. Vol. 4, No. 4 (hlm 39-54). 